\title{
鿻 \\ PEMIKIRAN GOLDZIHER DAN AZAMI TENTANG PENULISAN Hadis
}

\author{
Ahmad Isnaeni \\ IAIN Raden Intan Lampung \\ aisnaeni74@gmail.com
}

\begin{abstract}
Abstrak
Tulisan ini mendiskusikan pemikiran Ignaz Goldziher disandingkan dengan pemikiran Mustafa Azami, yang akrab dengan studi hadis di Barat. Alasan memilih sosok Goldziher, sebab pemikiran Goldziher dianggap sebagai pioner studi hadis di Barat. Pemikiran hadis Goldziher turut memberi warna secara turun temurun dalam tradisi kajian hadis di kalangan orientalis. Secara umum, sikap para orientalis dalam studi hadis (eksistensi hadis) terbagi dalam tiga kelompok besar, yaitu skeptis, sanguine (non-skeptis), dan middle ground. Dari bahasan ini akan terlihat bagaimana minat yang besar dalam diri Goldziher dan beberapa sarjana Barat lain atas kajian sunnah Nabi saw. Pada sisi lain, Azami turut meramaikan perbincangan tentang hadis dan sunnah Nabi saw. Pemikiran utama Azami adalah untuk menyingkap kelemahan dan kekeliruan sorotan Barat terhadap sunnah Nabi saw. Irama perdebatan yang diikuti oleh Azami dalam arus pemikiran Barat cukup memberi warna, meskipun dari beberapa kalangan Barat, hasil kajian Azami dinilai kurang obyektif dan bersifat apologis.
\end{abstract}

\section{Abstract}

GOLDZIHER'S THINKINGS AND AZAMI'S WRITING ABOUT HADITH. This paper discusses the thoughts of Ignaz Goldziher juxtaposed with the thoughts of Mustafa Azami who is familiar with the study of Hadith in the West. The reasons for choosing Goldziher, because he was considered as a pioneer of Hadith study in Western countries. In additin, his thoughts has also coloured for generations in the study of Hadith tradition among orientalists. In general, the attitude of the orientalists in the study of hadith (hadith existence) is divided into three major groups, namely skeptical, sanguine (non-skeptical), and the middle ground. From the discussion, it 
can be measured how great is the interest of Goldziher and some other Western scholars on the study of the Sunnah of the Prophet. On the other side, Azami helps to enliven the conversation about Hadith and Sunnah of the Prophet. Azami's main thought is to expose the weaknesses and the mistakes of the Western spotlight against the Sunnah of the Prophet. The rhythm of the debate followed by Azami in current Western thought is enough to give color, although to some Western circles, the results of Azami's study are considered less objective and apologetic

Kata Kunci: Penulisan hadis; otentisitas; historisitas

\section{A. Pendahuluan}

Ignaz Goldziher, bukanlah orang yang pertama kali memberi kritik terhadap hadis, namun demikian dirinya dianggap sebagai orang yang paling berpengaruh dalam mengembangkan kajian hadis di Barat. Secara umum pemikiran Goldziher tentang sunnah dan hadis tersimpul kepada tiga topik yakni; asal-usul hadis, perkembangan dan pemalsuan hadis, dan keberadaan literatur hadis. Ketiga topik tersebut mengarah kepada meragukan keotentikan hadis dan menolak bahwa hadis layak dijadikan sumber pengetahuan dan hukum. Dengan sistematis Goldziher menghadirkan pembahasan menarik atas persepsi dan vonisnya terhadap studi hadis. Hasil pemikiran Goldziher ini menjadi landasan dan pondasi utama lahirnya kajian hasil lebih detail di kalangan sarjana Barat.

Sebagaimana dimaklumi di kalangan Barat, Gustav Weil dan Aloys Sprenger dinilai sebagai peletak kajian hadis Barat dan sebagai penggerak munculnya kecenderungan Barat akan kajian sunnah dan hadis. Goldziher lebih jauh dari kedua tokoh di atas, dan telah menancapkan pondasi keraguan mengenai otentisitas hadis. Keraguan Goldziher akan hadis bermula dari penolakannya bahwa hadis bukanlah sebagai dokumen sejarah awal Islam, melainkan sebagai peninggalan dari berbagai refleksi tendensius umat Islam yang hidup belakang setelah kehidupan Nabi. Sebelum membahas lebih jauh bagaimana Goldziher memandang secara utuh sunnah dan hadis, perlu dikemukakan bahwa dalam pemaparannya, Goldziher tidak dapat melepaskan pijakan pandangannya dari sisi makna kebahasaan semata dan tidak berupaya mengikuti dan mengambil makna istilah sebagaimana yang berlaku di kalangan muslim. 


\section{B. Historisitas Hadis}

Goldziher mengartikan hadis secara bahasa sebagai berita yang berlaku di kalangan kelompok penganut kerohanian, catatan sejarah baik sekuler maupun keagamaan dari masa ke masa. Sementara sunnah dipahami sebagai tradisi dan kebiasaan yang ada di masyarakat baik setelah Islam datang ataupun sebelumnya, diikuti secara terus menerus dan dianggap sebagai peninggalan berharga yang mesti diikuti. ${ }^{1}$ Dalam uraian selanjutnya, Goldziher menyatakan bahwa hadis jika dimaksud sebagai sesuatu yang disandarkan kepada Nabi Muhammad, maka itu sulit akan diterima secara ilmiah, sebab hadis tiada lain adalah peninggalan umat Islam setelah kehidupan Nabi. Dengan kata lain yang ada bukan hadis tetapi sunnah. Dalam konteks ini sunnah dipahami Goldziher sebagai makna literernya yakni sebagai jalan hidup yang dilalui seseorang atau masyarakat. ${ }^{2}$

Menurut Goldziher, sunnah adalah ketentuan-ketentuan yang diyakini kebenarannya yang mengatur pola kehidupan masyarakat tertentu. Terkait dengan kehidupan masyarakat praIslam, sunnah telah ada sebagai perangkat tradisi dan kebiasaan leluhuryang menjadi sumber kebiasaan dalam kehidupan.Goldziher kemudian menekankan bahwa dalam Islam terminologi sunnah juga digunakan untuk sesuatu yang memiliki pemahaman yang sama. Sunnah pada mulanya dipahami sebagai perangkat tata nilai kehidupan masyarakat tertentu dalam perkembangannya dipahami sebagai tradisi dan pola kehidupan yang besifat universal. ${ }^{3}$ Secara khusus sunnah kemudian dipahami sebagai kebiasaan-kebiasaan tertentu baik teoritis maupun praktis dalam ibadah dan hukum kaum mukminin pertama yang telah dipraktikkan di bawah kesaksian Nabi. ${ }^{4}$ Sunnah dan hadistidaklah identik. hadis merupakan pernyataan-pernyataan tata cara itu, dan hadis tiada lain adalah

${ }^{1}$ Ignaz Goldziher, Muslim Studies, terj. S.M. Stern \& C.R. Barber, (London: George Allen \& Unwin, 1971), h. 17-26.

${ }^{2}$ Ignaz Goldziher, Muslim Studies..., h. 19.

${ }^{3}$ Ibid., h. 26-28.

${ }^{4}$ H.A.R Gibb \& J.H. Kramers, Shorter Encyclopaedia of Islam, (London: Luzac \& Co, and Leiden: E.J. Brill, 1961), h. 552. 
dokumentasi sunnah. ${ }^{5}$ Di sisi lain Goldziher berkeyakinan bahwa penggunaan sunnah sebagai pedoman hidup keagamaan di dunia Islam pada masa awal adalah suatu keyakinan yang dinilai keliru. Sebab menurutnya, sunnah tiada lain adalah penjelasan praktik kehidupan keagamaan dan interaksi social penduduk Madinah yang kemudian mendapat legitimasi konstitusional, sementara masyarakat di luar Madinah amat sulit untuk menerima sunnah sebagai pedoman kehidupan keagamaan. ${ }^{6}$

Goldziher lebih jauh menyatakan bahwa pada mulanya masyarakat Islam di luar kota Madinah amat sedikit pengetahuannya tentang ajaran Islam. Ajaran Islam masih merupakan sesuatu yang asing bagi masyarakatnya, sehingga banyak sekali ajaran ritual Islam yang belum diketahui apalagi diamalkan. Karena ketidaktahuan mereka akan ajaran Islam, termasuk ayat al-Qur'an maka merekapun tidak mampu membedakan antara ayat al-Qur'an dengan sya'ir-sya'ir yang berkembang. Eksistensi sunnah baru dikenal masyarakat luas dan menjadi norma Islam formal sejak akhir abad pertama Hijriyah. Pergerakan sunnah menjadi sumber hukum terjadi seiring pergumulan politik dan masyarakat antara abad kedua dan ketiga Hijriyah. Dengan ini keberadaan hadis dalam kumpulan kitab-kitab hadis yang nota bene memuat kumpulan sunnah-sunnah Nabi dan diakui kalangan muslim sebenarnya tidak menghadirkan keyakinan akan kebenarannya tetapi justru menimbulkan keraguan. ${ }^{7}$ Tetapi dalam perkembangan selanjutnya, seiring dengan berkembangnya teologi hadis antara abad kedua dan ketiga Hijriyah yang merupakan babak baru sejarah perkembangan hadis, kedudukan sunnah disetarakan dengan kitab suci dalam membentuk hukum. ${ }^{8}$

Berangkat dari pemikiran di atas, Goldziher memaknai hadis dengan "percakapan" atau "pemberitaan" yang ada di kalangan para penganut agama, kumpulan catatan historis berkaitan dengan kehidupan dunia dan akhirat baik dari masa lampau

${ }^{5}$ Ignaz Goldziher, Introduction to Islamic Theology dan Law, terj. Andras dan Ruth Hamori, (Princeton: Princeton University Press, 1981), h. 37.

${ }^{6}$ Zikri Darussamin, "Studi Atas Pemikiran Ignaz Goldziher”, Tesis, IAIN Sunan Kalijaga Yogyakarta, 1997, h. 61

${ }^{7}$ Ignaz Goldziher, Muslim Studies..., h. 25-32.

${ }^{8}$ Zikri Darussamin, "Studi Atas Pemikiran..., h. 61. 
ataupun sekarang. ${ }^{9}$ Sementara hadis dalam terminologi Islam menurut Goldziher dipergunakan untuk menunjukkan kepada ucapan dan perbuatan yang disandarkan kepada Nabi. Akan tetapi kenyataan yang ada dan perkembangan masa yang melingkupinya, hadis akhirnya tidak hanya berasal dari Nabi tetapi lebih kepada keinginan-keinginan yang ada dalam masyarakat muslim dalam kehidupannya. ${ }^{10}$ Goldziher menilai bahwa kemunculan hadis berangkat dari keseriusan umat Islam awal yang memberitakan hal ihwal dari sang Nabi atas segala apa yang dihadapi dalam kehidupan. Menurut Goldziher, Islam seperti halnya agama Yahudi, hukum agama dapat lahir di luar kitab suci yakni berdasarkan sunnah Nabi. ${ }^{11}$ Berdasarkan sunnah ini teori yang memberikan pengakuan baik terhadap hukum yang tertulis maupun hukum yang disampaikan secara lisan. Sunnah yang kemudian terdokumentasikan ke dalam hadis dipandang sebagai penjelas yang paling otoritatif al-Qur'an. ${ }^{12}$

Perkembangan hadis yang lebih meluas dikarenakan kesadaran umat Islam awal bahwa penuturan dan perilaku Nabi adalah petunjuk maka berita itu disampaikan kepada orang-orang yang dijumpainya, khususnya setelah terjadinya penaklukan daerahdaerah baru. Karena ingatan manusia terbatas, termasuk para muslim awal sementara keinginan menyampaikan berita tentang Nabi terus berlangsung maka terjadilah penambahan-penambahan di dalamnya. Goldziher menggarisbawahi peristiwa-peristiwa tadi penyebab utama munculnya pemalsuan hadis di masa awal, sehingga hadis lebih mudah dipahami sebagai keinginankeinginan tendensius umat Islam dalam rangka penyebaran ajaranajaran agama. ${ }^{13}$ Kemunculan hadis sebagai refleksi tendensius umat Islam belakangan, menurut Goldziher didasarkan pada kenyataan pada masa dinasti Umayyah telah terjadi pertentangan antara sang penguasa dengan para ulama. Antara kedua kelompok saling menekan satu sama lain, dan yang tersisih adalah kelompok para ulama. Keadaan ini memicu para ulama untuk menyibukkan diri kepada masalah keagamaan dengan memunculkan hadis-

\footnotetext{
${ }^{9}$ Ignaz Goldziher, Muslim Studies..., h. 17.

${ }^{10}$ Ibid., h. 19.

${ }^{11}$ H.A.R Gibb \& J.H. Kramers, Shorter Encyclopaedia ... h. 116

${ }^{12}$ Ignaz Goldziher, Introduction ..., h. 38.

${ }^{13}$ Ignaz Goldziher, Muslim Studies..., h. 18.
} 
hadis tertentu untuk melegitimasi gerakan mereka. Sementara itu kalangan penguasa tidak tinggal diam melihat apa yang dilakukan kelompok para ulama, dengan merekrut ulama tertentu pihak penguasa juga berupaya melakukan hal yang sama untuk mendukung program politiknya dalam rangka menyerang balik kalangan ulama yang kontra pemerintah. ${ }^{14}$

Goldziher menggambarkan kejadian yang sama juga muncul ketika masa pemerintahan dinasti Abbasiyyah antara aliran hukum klasik dengan para ahli hadis. Masing-masing kelompok mengklaim bahwa metode pendekatan mereka adalah yang benar sementara lainnya adalah salah. Hadis yang dimunculkan bukan saja membela pendapat mereka tetapi lebih jauh juga digunakan untuk menyokong apa yang dilakukan oleh para guru dan orang yang sealiran. Dengan kondisi inilah pemalsuan hadis semakin marak, sehingga semakin banyak hadis yang muncul bernuansa politik dan madzhab fikih semakin jelas bahwa hadis-hadis tersebut tidaklah dapat diakui keotentikannya. ${ }^{15}$

Untuk mendukung konsepsinya, Goldziher mengutip bukti adanya pemalsuan hadis untuk kepentingan kelompok-kelompok tertentu dan membela kelompoknya, sehingga tidak ada mazhab di bidang ritus, teologi, hukum, ataupun faksi-faksi politik yang akan kekurangan satu atau sekumpulan hadis yang menguntungkannya, dengan memperlihatkan segala tanda lahiriah tentang kebenaran periwayatannya. ${ }^{16}$ Inilah bukti bahwa otentitisas hadis layak diragukan. Tidak mungkin seorang Nabi lebih mengutamakan kelompok tertentu dan menekan kelompok lain, sementara munculnya faksi-faksi dimaksud jauh setelah masa kehidupan Nabi. Bukti dimaksud adalah adanya hadis yang memuat keutamaan sebuah kota, suku bangsa dan bahasa tertentu, keharusan akan kepatuhan kepada penguasa, dan masih banyak lainnya. ${ }^{17}$

Goldziher menegaskan bahwa mestinya kita tidak mengesampingkan kemungkinan hadis yang diriwayatkan oleh generasi-generasi selanjutnya terkadang mengandung pengertian-

\footnotetext{
${ }^{14}$ Ignaz Goldziher, Muslim Studies..., h. 40-43.

${ }^{15}$ Ibid., h. 97.

${ }^{16}$ Ignaz Goldziher, Introduction..., h. 39.

${ }^{17}$ Ignaz Goldziher, Muslim Studies..., h. 45, 90-96.
} 
pengertian dari bahan lama yang tidak langsung berasal dari katakata Nabi, tetapi berasal dari generasi tokoh-tokoh terkemuka orang Islam yang pertama. Selain itu, lanjut Goldziher, karena jarak waktu yang cukup jauh tentu kemungkinan terjadi banyak orang mengatakan suatu perkataan yang dinisbatkan kepada Nabi, yang seakan diriwayatkan melalui mata rantai ke belakang sampai kepada tokoh-tokoh terkemuka paling tinggi yakni Nabi dan sahabatnya. Tujuannya tiada lain yakni untuk mendapatkan legitimasi dari mereka dan mengesahkan tujuan doktrin teoritis maupun doktrin praktis. ${ }^{18}$

Setelah Nabi saw wafat, Islam telah meluas ke berbagai daerah di semenanjung Arab. Kemudian seiring dengan banyak daerah yang dikuasai oleh umat Islam maka semakin banyak pula para sahabat Nabi saw yang ditugaskan untuk menjadi penyebar syariat Islam. Beberapa daerah dimaksud di antaranya negeri Irak dan Syam secara keseluruhan, di mana kala itu meliputi beberapa tempat yakni Palestina, Ardan, Syiria, dan Libanon di tahun 17 Hijriyah. Penaklukan Mesir pada tahun 20 Hijriyah, Persia di tahun 21 Hijriyah, Daerah Samarkand di tahun 56 Hijriyah, dan Islam sampai ke Andalusia di tahun 93 Hijriyah. ${ }^{19}$ Di daerah-daerah taklukan umat Islam itu para sahabat yang menjadi motor penggerak syiar Islam berpencar menyebarkan ajaran Islam. Orang-orang yang hidup semasa dengan sahabat itu mendapat pengajaran dan pendidikan tentang Islam, baik al-Qur'an maupun sunnah Nabi saw.

Hasil dari penyebaran ajaran Islam sejak sahabat, tabi'in dan orang-orang sesudahnya dapat dilihat betapa banyak daerah-daerah menjadi pusat studi Islam, khususnya kajian hadis Nabi. Sebut saja di antaranya Madinah, Mekkah, Kuffah, Basrah, Syam, Mesir, Maghrib dan Andalusia, Yaman, Jurjani, Quzwain, dan Khurasan. ${ }^{20}$ Berbeda dengan Goldziher, perjalanan mencari hadis itu sebenarnya bukan semata-mata mendapatkan hadis yang orisinal. Akan tetapi tidak terlepas dari bentuk pemalsuan hadis. Menurut Goldziher, di dalam mengumpulkan hadis banyak penyisipan kalimat (tadlis)

${ }^{18}$ Ignaz Goldziher, Introduction ..., h. 39.

${ }^{19}$ Muhammad Ajjaj al-Khatib, Ușūl al-Ḥ̄àdìs ‘Ulūmuhu wa Musthalahuh, (Beirut: Dār al-Fikr, 1975), h. 115-116.

${ }^{20} \mathrm{Ibid}$..., h. 116-135. 
yang bukan kata-kata dari suatu hadis. Ini dampak dari minimnya kritik di antara mereka yang lebih mengedepankan kritik sanad dan tidak fokus pada sisi matan. ${ }^{21}$

Disebabkan hanya bertumpu pada kritik sanad semata, Goldziher menilai bahwa apa yang dilakukan oleh para ulama dalam melakukan kritik hadis tidak maksimal. Di samping hanya menitikberatkan pada kritik sanad, juga bersifat formal sementara aspek materialnya tidak menjadi sasaran kritik. Kebanyakan para ulama memberikan penilaian sahih kepada suatu hadis meski hanya selesai pada tataran sanad, seringkali matan hadis diabaikan dari telaah kritis. ${ }^{22} \mathrm{Hal}$ ini juga akan membuat semakin sulit untuk menemukan keobyektifan ulama dalam memberikan penilaian, sebab bisa saja penilaian tersebut bertumpu pada sisi-sisi sikap antara suka dan tidak suka terhadap seorang periwayat. ${ }^{23}$

Herbert Berg menyitir pandangan Goldziher, bahwa kritik hadis baru muncul setelah tahun 150 Hijriyah akibat dari maraknya pemalsuan hadis. Pelaksanaan kritik hadis ini ternyata tidak dapat menghilangkan kebiasaan dari kalangan muslim yang memalsukan hadis. Salah satu cara yang mereka lalui adalah dengan membuat suatu redaksi hadis kemudian menyusun rangkaian sanad yang memuat nama-nama orang terpercaya dan dikenal oleh para kritikus hadis dengan diakhiri oleh orang-orangyang telah lanjut usia dengan harapan merekalah yang melakukan kontak langsung dengan Nabi, yakni kalangan sahabat. Ketika ditelaah dan dikonfirmasi melalui awal kelahiran dan kelangsungan hidup dari nama-nama orang yang dilibatkan dalam periwayatan hadistersebut ada yang berusia lebih dari satu abad, sesuatu yang mengherankan. ${ }^{24}$

\section{Keraguan atas Penulisan Hạāis}

Goldziher tampak sepakat dengan pandangan sementara pemikir muslim yang menyatakan bahwa penulisan hadis telah dilakukan sejak generasi pertama Islam. Bentuk dari hasil penulisan tersebut adanya naskah-naskah yang dinisbahkan kepada beberapa

\footnotetext{
${ }^{21}$ Ignaz Goldziher, Muslim Studies..., h. 168.

${ }^{22}$ Ibid., h. 123-130.

${ }^{23}$ Ibid., h. 130-144.

${ }^{24}$ Herber Berg, The Development..., h. 11.
} 
sahabat yang disebut șahịfah. Kesepakatan Goldziher terletak pada pengakuan adanya naskah-naskah tersebut yang memuat hadishadis yang disandarkan kepada Nabi. Akan tetapi penulis awal dari naskah tersebut menjadi sesuatu yang perlu diragukan, apakah memang para sahabat itu yang melakukan penulisan ataukah orangorang yang datang sesudahnya lalu untuk mendapatkan legitimasi naskah itu dinisbatkan kepada diri sahabat. Tidak bisa dipungkiri, demikian Goldziher menambahkan, bahwa generasi awal Islam telah melakukan pemeliharaan terhadap peninggalan-peninggalan Nabi, baik al-Qur'an maupun sunnah Nabi. Tetapi hanya bersifat lisan semata, jika ada bukti tulisan yang memuat tentang hadis kemungkinan buatan orang yang hidup sesudah mereka. ${ }^{25}$

Menurut Goldziher, pengoleksian hadis dalam bentuk fikih sesuai dengan kebutuhan masyarakat yang mengharapkan adanya suatu buku yang memuat tentang tuntunan Nabi dalam dalam bidang hukum dan keagamaan. Maka Malik bin Anas mencoba menyusun kitab muwaț' sebagai jawaban dari persoalan dan permintaan masyarakat ketika itu. ${ }^{26}$ Menurutnya, bentuk pengoleksian hadis pada masa ini menggunakan dua metode yakni musnad; suatu kompilasi hadis yang disusun berdasarkan urutan nama-nama periwayatnya, dan muṣannaf; suatu kompilasi hadis yang disusun berdasarkan topik atau tema bahasan. Dari kedua metode yang digunakan, tampaknya metode mușannaf lebih banyak diminati oleh para ulama seperti kutub as-sittah. ${ }^{27}$ Bagaimanapun, Goldziher mengakui keberhasilan umat Islam dalam menyusun kitab-kitab hadis yang merupakan hasil upaya kritik hadis yang dilakukan para ulama terwujud dalam kutub as-Sittah. Termasuk Malik bin Anas dengan kitab muwaț'nya yang memuat hadis-hadis fikih secara sistematis. Meskipun menurut Goldziher kandungan di dalam kitab Malik bin Anas tersebut tidak lain memuat tradisi kebiasaan masyarakat Madinah, sebagai tempat munculnya sunnah. ${ }^{28}$

\footnotetext{
${ }^{25}$ Ignaz Goldziher, Muslim Studies..., h. 82.

${ }^{26}$ Ibid., h. 97.

${ }^{27}$ Ibid., h. 214.

${ }^{28}$ Ignaz Goldziher, Introduction..., h. 39.
} 


\section{Kritik Azami atas Pemikiran Goldziher}

Bantahan Azami terhadap pemikiran hadis Barat, khususnya Goldziher dan Schacht, paling tidak melalui dua langkah utama; pertama, menelaah dan membantah argumentasi pemikiran para orientalis yang ada, dan kedua, mengkritisi keakuratan sumber literatur yang menjadi landasan teori dan pandangan mereka. ${ }^{29}$ Azami seringkali mengklaim bahwa sarjana Barat, khususnya Schacht tidak konsisten dalam metode dan materi sumber, berlandaskan asumsi salah dalam penelitian, dan kesalahan dalam memahami ungkapan ulama terdahulu. ${ }^{30}$ Berikut ini akan diuraikan kritik Azami atas pemikiran Goldziher dan Schacht tentang hadis.

\section{Asal-usul Hadis}

Untuk mengurai bantahan Azami atas teori dan pemikiran hadis para orientalis, berikut ini akan diawali dengan bantahan yang dikemukakan Azami adalah terkait makna hadis yang dipahami para orientalis, Goldziher. Menurut Azami terdapat kesalahan di dalam memahami makna Sunnah dan hadis dalam pandangan mereka. Dalam suatu kesempatan Goldziher mengatakan bahwa sebelum Islam kemudian diadopsi oleh orang-orang Islam. ${ }^{31}$ Menurut Azami pandangan, Goldziher ini tidak berdasarkan argumen yang dapat dipercaya sama sekali dan bertentangan dengan dalil-dalil yang ada. Tradisi yang berkembang dalam dunia Islam dan dilakukan oleh kalangan muslim sebenarnya tidak dapat lepas dari tradisi kebiasaan orang-orang sebelum Islam datang. Kebiasaan-kebiasaan perilaku yang dilakukan Nabi saw dan umat Islam juga sama dengan kebiasaan-kebiasaan orang yang ada masa sebelumnya, tetapi hal ini tidak berlaku dalam masalah hukum dan keyakinan.

Menurut Azami, Kata sunnah memang berasal dari bahasa Arab dan telah dipakai sejak masa pra-Islam. Kata tersebut diartikan

\footnotetext{
${ }^{29}$ Menurut telaah Gusdur, dua rangka besar telaah Azami atas pemikiran orientalis tersebut dilanjutkan secara detail atas beberapa pemikiran mereka. Meski demikian Gusdur juga menilai bahwa pekerjaan Azami masih belum secara komprehensif mematahkan teori dan pemikiran Barat atas hadis. Hasil kerja Azami hanya menyorot beberapa aspek yang central, sementara masih banyak pemikiran Barat yang cenderung menyerang hadis dan belum tersentuh. Lihat Abdurrahman Wahid et.al., "Sumbangan M.M. Azami..., h. 38-46.

${ }^{30}$ Azami, On Schacht's..., h. 117-122.

${ }^{31}$ Ignaz Goldziher, Introduction.., h. 97.
} 
secara bahasa sebagai tata cara, perilaku hidup, syariah, dan jalan hidup, terpuji atau tercela. ${ }^{32}$ Kata sunnah ini dapat ditemukan di berbagai syair Arab pra-Islam maupun sesudah masa Islam. ${ }^{33}$ Goldziher dan Schacht dipandang oleh Azami terjebak dalam memahami makna sunnah sebagai masalah yang ideal dan norma yang disepakati masyarakat. ${ }^{34}$ Jadi sunnah Nabi saw lepas dari aturan dan tradisi orang-orang pra-Islam. ${ }^{35}$ Azami menegaskan, tradisi kebiasaan dan perilaku kehidupan Nabi saw jauh berbeda dengan sunnah yang dilakukan orang-orang jahiliyah dan animis. Sedangkan tradisi Nabi saw tersebut tidak dibangun atas dasar mengadopsi tradisi sebelumnya, bahkan Nabi saw berupaya merubah dan menghindari tradisi kebiasaan yang salah. Meski ada pula tradisi yang diikuti tetapi tidak berkisar pada masalahan hukum dan kebiasaan yang menyimpang dari doktrin Islam. ${ }^{36}$

Azami menyangkal sunnah diartikan dengan adat istiadat dan kebiasaan masyarakatIslam, kemudian dalam perkembangannya dirujukkan hanya kepada tradisi yang dibangun dari Nabi. Sebab jika demikian, berarti sunnah Nabi tiada lain adalah merupakan tradisi masyarakat Islam lalu dikhususkan penamaannya untuk sunnah Nabi. Sunnah Nabi adalah perilaku dan teladan Nabi dalam menjalankan syari'at Islam. ${ }^{37}$ Berangkat dari pemahaman literer ini lalu digeneralisasikan termasuk sunnah Nabi tiada beda dengan sunnah orang lain, bahkan sebelum Islam datang. ${ }^{38}$ Sunnah Nabi itu benar-benar dari perilaku dan kebiasaan yang dibangun atas dasar bimbingan wahyu, sementara umat Islam memang diperintahkan

\footnotetext{
${ }^{32}$ Azami, Hadis Nabawi........ h. 21.

${ }^{33}$ Ibid., h. 14-15.
}

${ }^{34}$ Schacht sepakat dengan Snouck Hurgronje dalam memahami sunnah sebagai 'the sunna of the Prophet, that is, his model behaviour, the consensus of the orthodox community' di mana dalam perkembangannya, Schacht juga sepakat dengan Goldziher dan Margoliouth, dalam memahami konsep sunnah, yakni model kehidupan Nabi, preseden, jalan hidup, tradisi yang hidup, yang diadop dari orang animis, norma ideal suatu masyarakat. Lihat Joseph Schacht, The Origins..., hal. 1, 5, dan 59. Bandingkan dengan Ahmed Hasan, The Early Development of Islamic Jurisprudence, edisi ke-1, (Delhi, India: Adam Publishers \& Distributors, 1994), h. 91.

\footnotetext{
${ }^{35}$ Azami, Hadis Nabawi......... h. 20.

${ }^{36}$ Ibid., h. 21.

${ }^{37}$ Ibid., h. 25.

${ }^{38}$ Ibid., h. 10, dan h. 21-24.
} 
untuk mengikutinya. Adapun kebiasaan sahabat setelah sepeninggal Nabi, jika bertentangan dengan sunnah Nabi tentu sunnah Nabi yang lebih didahulukan. Hal ini pernah digambarkan oleh Ibnu Umar yang memberi pertimbangan keutamaan untuk mendahulukan sunnah Nabi dari sunnah Umar. Sebab kewajiban yang mesti diikuti adalah sunnah Nabi, bukan sunnah yang lain. ${ }^{39}$

Azami menggarisbawahi bahwa sunnah secara bahasa memang berarti tata cara, tradisi, dan perilaku hidup, baikitu bersifat positif ataupun negatif. Definisi ini juga dipergunakan dalam Islam untuk merujuk makna yang sama, lalu dalam perkembangannya, kata tersebut diperuntukkan hanya untuk merujuk kepada tata cara Nabi saw..$^{40}$ Meskipun kalangan bangsa Arab tetap menggunakan istilah sunnah ini dalam arti sempit, yakni tata cara, kebiasaan, dan tradisi. Ini bukan berarti penggunaan kata sunnah merujuk kepada makna yang biasa digunakan masyarakat Arab, apalagi merujuk kepada penggunaan masyarakat Arab jahiliyah. Dengan demikian, kata sunnah dipakai untuk menunjukkan tata cara Nabi saw dalam perkembangannya, seringkali dibubuhi awalan "al" untuk membedakan antara sunnah Nabi dengan sunnah-sunnah yang lain. Masyarakat Islam sejak dahulu tidak pernah menggunakannya untuk arti "kebiasaan masyarakat" tetapi berpulang kepada diri Nabi saw. ${ }^{41}$

2. Periwayatan dan penulisan hadis

Terkait dengan pandangan Goldziher mengenai perkembangan hadis di masa-masa selanjutnya, di mana disebutkan bahwa hadis dari hari ke hari jumlahnya semakin membengkak dan ini merupakan rekayasa umat Islam untuk menyebarkan ajaran Islam dan kemudian disandarkan kepada orang-orang sebelumnya sam-

\section{${ }^{39}$ Ibid., h. 25.}

${ }^{40}$ Kritik Azami atas pemikiran Ahmed Hasan yang cenderung tidak memilah antara sunnah Nabi, sunnah sahabat, sunnah ahli fiqh, dan lainnya. Sehingga akan terbius seperti uraian Schacht yang menggambarkan perkembangan sunnah dari masa ke masa sebagai perkembangan sunnah Nabi. Seakan sunnah Nabi belum terbentuk secara utuh di masa awal Islam dan mengalami bentuk sempurna di masamasa abad kedua dan ketiga hijriyah. Lihat Ahmed Hasan, The Early Development..., h. 86-87; Joseph Schacht, The Origins..., h. 1-189 (bab I dan II dalam bukunya); Azami, Hadis Nabawi, h. 10.

${ }^{41}$ Azami, On Schacht's..., h. 38 dan Azami, Hadis Nabawi, ..... h. 26. 
pai kepada diri Nabi. Ini terjadi sebab tidak adanya periwayatan melalui tulis-menulis sehingga sulit mencari riwayat yang akurat dan orisinal. ${ }^{42}$ Lebih nyata lagi setelah pertentangan politik antara Bani Umayyah dengan kalangan ulama. Demikian pula masa khalifah Bani Abbasiyah yang mengadakan konfrontasi dengan kalangan aliran fiqih klasik. Masing-masing menurut Goldziher telah berkontribusi memunculkan hadis-hadis palsu. ${ }^{43}$

Untuk menanggapi pandangan Goldziher, perlu menelaah proses periwayatan hadis kalangan sahabat dan tabi'in, sebagian mereka ada yang melalui lisan, dan adapula melalui proses tulis menulis. Azami menyebutkan terdapat enam puluh orang sahabat yang menjadi 'sekretaris' Nabi. ${ }^{44}$ Jumlah tersebut dikelompokkan secara umum kepada kelompok Quraisy Muhajirin, Bani Saqif, dan Anṡār. Dalam menjelaskan lebih detail, Azami menyetujui pembagian yang dilakukan oleh al-Baqilani kepada empat kelompok; 1) yakni mereka yang diketahui sebagai sekretaris Nabi; 2) sahabat Nabi yang dikenal mampu tulis-baca; 3) sahabat Nabi yang tidak ada keterangan yang jelas bahwa mereka mampu tulisbaca; dan 4) mereka yang tidak ditemukan dalam kumpulan kitab biografi sahabat. ${ }^{45}$ Masing-masing sekretaris itu jika dilihat dari sisi intensitas menulis untuk Nabi tentu memiliki perbedaan. Azami mengelompokkan kepada tiga; pertama, kelompok yang memang dikenal sebagai sekretaris Nabi, seperti Ali bin Abi Tālib, Usman bin Affan, Zaid bin Sabit dan lainnya. Kedua, mereka yang dikenal sebagai sekretaris tetapi frekuensi menulisnya lebih rendah dari pertama. Di antara mereka adalah Abu Bakar aṣ-Ṣiddiq, Umar bin Khattab, Abu Ayyub al-Anșāri dan lainnya. Ketiga, kelompok sahabat yang tercantum dalam kitab al-Wäa'iqus Siyasiyyah dan kitab lain tetapi Azami tidak menemukan ketegasan bahwa mereka sekretaris Nabi. ${ }^{46}$

${ }^{42}$ Ignaz Goldziher, Introduction..., h. 43-44.

${ }^{43}$ Ibid., h. 36-38.

${ }^{44}$ Azami tidak konsisten dalam menyebut jumlah sekretaris, meski ungkapan yang digunakan adalah Nabi paling tidak memiliki 45 juru tulis. Lihat M.M. Azami, Studies in Hadith Methodology and Literature, (Indianapolis: American Trust Publications, 1977), h. 10.

${ }^{45}$ M.M. Azami, 65 Sekretaris Nabi Shallallahu 'Alaihi wa Sallam, terj. Mahfuzh Hidayat Lukman, cet. ke-1, (Jakarta: Gema Insani Press, 2008), h. xx-xxv.

${ }^{46}$ Ibid., h. Xxx. 
Azami memasukkan sahabat ke dalamnya tetapi dirinya sendiri mengakui bahwa itu tidak berdasarkan informasiyang akurat dan pasti. Berbeda dengan al-Mas'udi dalam kitab at-Tanbih wa al-Isyrāf yang dirujukAzami sebagai pembanding atas dasar pengelompokkan sekretaris Nabi yang dilakukannya. Seraya mengkritik metode yang dilalui oleh al-Mas'udi yang hanya memasukkan sahabat sebagai sekretaris Nabi jika intensitas menulis untuk Nabi cukup banyak. Jalan yang dilalui Azami dalam mengkategorikan sahabat sebagai sekretaris Nabi tanpa memperhatikan intensitasnya. ${ }^{47}$

Inti uraian tentang sekretaris Nabi tersebut tentu tidak terpaku kepada jumlah sahabat yang menjadi sekretaris Nabi, tetapi untuk membantah pandangan Barat, khususnya Goldziher sebagaimana di atas. Menurut Ali Mustafa Yakub, sebab meski bangsa Arab masa Jahiliyah dan awal Islam dapat dikategorikan sebagai bangsa 'Ummi' tentu bukan berarti semuanya tidak ada yang pandai tulis-baca. ${ }^{48}$ Asumsi ini akan terbantah dengan adanya syair-syair yang ada baik sejak masa jahiliyah maupun awal kedatangan Islam. Selain itu Azami meminjam istilah Ibnu Sa'ad, terdapat ungkapan "minal kāmilina" (di antara orang-orang yang sempurna) pada masa jahiliyah dan permulaan Islam salah satunya adalah orang yang dikenal mampu menulis Arab, selain berenang dan permainan panah. Sehingga ketika Islam datang, bangsa Arab hanya sekitar tujuh belas orang saja yang pandai menulis. Berkat usaha Nabi saw yang memerintahkan belajar tulis-baca, tidak lama banyak sahabat yang pandai menulis mencapai enam puluhan sahabat. ${ }^{49}$

Di antara penyebaran hadis melalui tulisan dapat dikategorikan di sini adalah surat-surat Nabi yang dikirim untuk para raja, penguasa, kepala suku, dan gubernur muslim yang ada. Selain juga catatan-catatan khusus untuk para sahabat, seperti Ali bin Abi Talib, Abdullah bin 'Amr bin Aș, dan Abu Syah. ${ }^{50}$ Azami menyebut Abu Hurairah yang dikenal salah satu sahabat yang banyak memiliki riwayat hadis juga memiliki buku yang memuat

${ }^{47}$ Ibid.,h. xxx-xxi.

${ }^{48}$ Ali Mustafa Yakub "Kata Pengantar" dalam M.M. Azami, 65 Sekretaris Nabi...h. xiii.

${ }^{49}$ M.M. Azami, 65 Sekretaris Nabi..., h. 1-5.

${ }^{50}$ M.M. Azami, Studies in Hadith Methodology..., h. 10. 
catatan hadis dan diberikan kepada para muridnya. Anas bin Malik memberikan catatan-catatan hadis kepada enam belas orang, Aisyah setidaknya memberikan catatan hadis kepada tiga orang, termasuk keponakannya sendiri yakni Urwah seorang tabi'in, dan masih banyak lagi sahabat Nabi yang meriwayatkan hadis dan memberikannya kepada para muridnya dalam bentuk tertulis. ${ }^{51}$

Sebagaimana dimaklumi, perhatian sahabat terhadap ajaran Islam yang mereka peroleh dari Rasulullah amat serius. Keseriusan ini terlihat dengan semangat mereka dalam mengikuti pelajaran Rasulullah. Kadangkala Rasul berada di atas mimbar, atau duduk di antara lingkaran (halaqah) sahabat untuk mengajarkan hal-hal penting masalah agama. ${ }^{52}$ Jumlah sahabat yang ikut pengajaran Nabi saw tidak mesti sesuai dengan kesempatan mereka mengikutinya. Azami menyebut, jumlah kalangan sahabat yang ikut menggali ilmu terkadang mencapai enam puluh orang. Hadis yang mereka terima tidak serta merta mereka hafalkan tetapi seringkali didiskusikan setelah proses penyampaian dari Nabi saw untuk memantapkan pemahaman mereka. Sehingga para sahabat banyak menghafal hadis ketika Nabi saw masih hidup. ${ }^{53}$

Upaya menjaga keakuratan hafalan, para sahabat adakalanya memperdengarkannya di hadapan Nabi saw. Keseriusan ini terlihat dari pengalaman seseorang yang diutus oleh Abd al-Qāis pada saat menghadap Nabi saw mendapat antrean untuk diperiksa hafalannya. Kritik Nabi saw atas hafalan para sahabat seringkali menjadi pengingat akan kesalahan mereka. ${ }^{54}$ Seiring dengan kesibukan untuk memenuhi kebutuhan hidup, para sahabat mengatur kehadiran mereka untuk mengikuti pengajaran Nabi saw. Adakalanya sebagian hadir sementara yang lain menjalani rutinitas keseharian. Sepulang dari kehadiran majlis Nabi saw informasi yang didapatkan kemudian disampaikan kepada yang

${ }^{51}$ Ibid., h. 26-27.

${ }^{52}$ M.M. Azami, Studies In Early Hadith Literature With A Critical Edition of Some Early Tekts, (Beirut: Al-Maktab al-Islami, 1968), h. 183.

${ }^{53}$ Ahmad Umar Hasyim, as-Sunnah an-Nabawiyah wa 'Ulūmuha, (Fajalah: Maktabah Gharib, t.t), h. 49.

${ }^{54}$ M.M. Azami, Studies In Early Hadith... hal. 184. Bandingkan dengan M.M. Azami, Dirāsah fi al-hadis..., jld. II, h. 331. 
tidak hadir. Umar bin Khațtab dan 'Itbān bin Malik sebagai contoh yang mempraktekkan metode ini. ${ }^{55}$

Anjuran untuk menjaga keberadaan hadis tidak hanya sebatas menghafal atau menyimpannya dalam bentuk tulisan, tetapi menyampaikan kepada orang yang ada di sekelilingnya. Banyak ditemukan informasi betapa besar minat umat Islam kala itu terhadap peninggalan nabinya, khususnya hadis-hadis Nabi saw yang memang memuat berbagai masalah keagamaan sebagai penjelas kandungan al-Qur'an. Para khalifah yang empat dan beberapa sahabat banyak mendapatkan informasi hadis, misalnya Abdullah bin Mas'ud. Ibnu Mas'ud ini membiasakan berada bersama Nabi untuk mendapatkan pelajaran tentang Islam. ${ }^{56}$ Pada perkembangan selanjutnya banyak bermunculan șahifah-șahifah yang memuat hadis Nabi di abad ketiga Hijriyah. Abu Hasan anNadwi pernah berpandangan șahifah-ṣahifah tersebut merupakan sumber-sumber utama kitab hadis di abad ketiga Hijriyah dalam bentuk kitab Jawami', masanid, dan sunan. Akan tetapi berita yang masyhur terdapat di kalangan umat Islam bahwa hadis baru ditulis dan tercatat di abad ketiga Hijriyah, sementara tadwin hadis baru dimulai di abad kedu Hijriyah. ${ }^{57}$ Ada dua faktor utama munculnya pendapat tersebut, pertama ahli sejarah hanya mendasarkan pandangannya terkait tadwin hadis di abad ketiga tanpa menyebut Șahifah-Șahifah dan kumpulan-kumpulan tulisan yang telah ada pada abad pertama Hijriyah. Kedua, ahli hadis tidak menyebutkan adanya kitab-kitab hadis yang banyak dan tebal-tebal merupakan hasil himpunan hadis yang berasal dari lemabran-lembaran kecil dan catatan-catatan yang berserakan sejak abad pertama Hijriyah. ${ }^{58}$

Beberapa metode periwayatan hadis di atas tidak berarti lepas dari kesalahan. Kesalahan ini muncul dari berbagai metode yang dipakai. Sebab-sebab kesalahan dalam penerimaan hadis seringkali terjadi kali kurang teliti dalam menulis atau memperhatikan imla'

${ }^{55}$ al-Asqalāni, Syihab ad-Dīn Abi al-Fadl bin Ḥajar (773-852 H), Fath al-Bāri bi Syarh al-Bukhāri, jld. I, (Kairo: Maktabah Mustafa al-Bābi al-Halabi, 1951 M/1378 H), h. 167; M.M. Azami, Studies In Early Hadith... h. 184, khususnya pada catatan kaki nomor 2 tentang Umar.

${ }^{56}$ Ibid., h. 50.

${ }^{57}$ Ibid., h. 56.

${ }^{58}$ Ibid. 
sang guru. Selain itu tidak dilakukan pengecekan akan kebenaran dan keakuratan penulisannya. Untuk mencegah terjadinya kesalahan ini, para ahli hadis melakukan koreksi atas berbagai catatan yang mereka terima dari sang guru, para murid biasanya membacakan hasil tulisan yang telah disampaikan guru, atau memperlihatkannya, atau membandingkan dengan tulisan kawan yang ikut pengajaran guru. ${ }^{59}$

Proses belajar para sahabat menurut kebanyakan ulama melalui metode lisan dalam penyampaiannya. Meski demikian tidak berarti penulisan hadis sama sekali tidak terjadi. Abu Hurairah mengakui kelebihan Abdullah bin Umar atasnya terkait hal ini, ia menyadari bahwa dirinya lebih mengutamakan hafalan dalam penyampaian hadis, berbeda dengan Ibnu Umar, selain berpedoman dengan lisan juga menulis hadis. Selain Ibnu Umar yang serius dalam menulis riwayat hadis adalah Abdullah bin Mas'ud dan Zaid bin Śabit, meski Zaid diberi tugas oleh Nabi untuk menulis ayatayat al-Qur'an di masa turunnya. ${ }^{60}$

Sementara itu, terdapat nama-nama yang dimunculkan Azami sebagai pelopor kalangan tabi'in yang gemar memotivasi koleganya untuk tetap fokus dalam menghafal hadis, di antaranya Ibnu Abi Laila, Abu al-'Aliyah, az-Zuhri, Talq bin Ḥabỉb, 'Urwah bin Zubair, dan 'Alqamah. Tradisi ilmiah ini kemudian memunculkan buku-buku yang memuat kumpulan hadis. Azami mengisyaratkan bahwa kitab hadis yang pertama kali muncul dari kalangan tabi'in adalah kitab Basȳ̄r bin Nahīk dan Hammam bin Munabbih. Keduanya merupakan murid dari Abu Hurairah. ${ }^{61}$

Azami bersikukuh pada pandangannya bahwa dalam penyebaran hadis tidak hanya menggunakan metode lisan tetapi juga tulisan. Alasan yang digunakan untuk membangun teori dan pandangannya ini, Azami memberi koreksi bahwa kebanyakan ulama hanya menerima pendapat yang mayoritas beredar dan yang diketahui. Padahal jika ditelaah lebih jauh terdapat informasi yang membeberkan banyak penulis hadis baik dari kalangan sahabat

${ }^{59}$ Ibid., h. 197.

${ }^{60}$ ad-Darimi, Abi Muhammad Abdullah bin Bahram, Sunan ad-Dārimi, jld. I, (Beirut: Dār al-Fikr, 2005), h. 92. Al-Asqālani, Fath al-Bāri..., jld. Ke-1, h. 184.

${ }^{61}$ M.M. Azami, Studies In Early Hadith..., h. 185. 
maupun generasi sesudahnya yang serius dalam penulisan hadis. Khususnya terbawa perdebatan dari adanya hadis yang melarang dan membolehkan menulis hadis. ${ }^{62}$

Kritik Azami atas pandangan Ibnu Hajar yang ikut meramaikan adanya larangan dalam menulis hadis yang terdapat dalam Fath al-Bäri menurutnya bermuara pada tiga faktor; pertama, kebanyakan sahabat tidak dapat menulis; kedua, kekuatan hafalan dan kecerdasan mereka cukup untuk menjaga keutuhan hadis, sementara menulis hadis dipandang kurang diperlukan, dan ketiga, adanya larangan untuk menulis hadis karena adanya kekhawatiran Nabi saw akan tercampur dengan al-Qur'an. ${ }^{63}$ Sementara itu, perhatian terhadap hadis tidaklah demikian. Penulisan dan pencatatan hadis baru dilakukan orang-perorang kalangan sahabat demi kebutuhan dan kepentingan mereka masing-masing. ${ }^{64}$

Kenyataan ini telah memicu berbagai spekulasi berkaitan dengan otentisitas hadis. Disebabkan lamanya tenggang waktu antara Rasulullah dengan masa pembukuan hadis ini, menjadikan hadis sebagai sasaran empuk bagi orang yang tidak senang dengan agama Islam, khususnya oleh sarjana orientalis yang ingin menginginkan agar umat Islam tidak percaya kepada hadis, atau paling tidak membuat umat Islam meragukan sumber hukum Islam yang kedua itu dari hasil penelitian yang mereka lakukan. G. Schoeler (Jerman) menyebutkan, isu yang menjadi perdebatan utama adalah pengumpulan hadis dan penyusunannya ke dalam sebuah buku. Ini berawal dari kesimpangsiuran informasi dan pandangan penggunaan isnad dalam riwayat, serta transmisi hadis melalui lisan atau juga tulisan. ${ }^{65}$

Istilah kodifikasi ini sering diidentikan dengan kata Arab kitābah, tadwīn, tașnîif. Sebagian mereka ada yang menyamakan kata-kata tersebut kepada upaya penghimpunan hadis ke dalam suatu kitab. Jika hal ini yang terjadi tentu pemahaman di atas akan mereduksi beberapa makna yang terkandung di dalam

${ }^{62}$ Ibid., h. 19.

${ }^{63} \mathrm{Ibid}$.

${ }^{64}$ M.M. Azami, Studies In Early Hadith..., h. 34-59.

${ }^{65}$ Gregor Schoeler, The Oral and The Written in Early Islam, Trans. Uwe Vagepohl, diedit oleh James E. Montgomery, cet. Ke-1, (London and New York: Routledge Taylor and Franch Group, 2006), h. 28. 
masing-masing kata yang ada. Padahal kata-kata tersebut memiliki kandungan arti yang berbeda, meski dalam batasan tertentu memiliki kesamaan. Menurut telaah Azami, banyak bermunculan pemahaman kepada istilah kitābah, tadwīn, tașnîf. yang tidak tepat, ini berakibat kepada kesalahan dalam memahami tentang penulisan hadis. ${ }^{66}$ Tujuan dari bahasan ini adalah untuk mengomentari pandangan yang menyatakan bahwa kodifikasi hadis baru dimulai sejak akhir abad pertama Hijriyah atas instruksi Umar bin Abdul Aziz kepada Ibnu Syihab az-Zuhri. Motzki berkomentar, masa Nabi saw dan sahabat, sedikit sekali -atau bahkan tidak ada-orang yang menulis hadis, sebab mereka masih menggunakan lisan dan mempraktekkan kandungannya. ${ }^{67}$

Kitābah secara bahasa berasal dari kata kataba, memiliki arti penulisan. Menurut Ibnu Faris ${ }^{68}$, kataba adalah mengumpulkan sesuatu yang tercerai berai, berserakan ke dalam sesuatu yang terkumpul (lembaran-lembaran), kemudian kumpulan lembaran tersebut dijadikan satu disebut kitab. kitābah al-hadis yakni penulisan hadis dilakukan sejak masa sahabat dan tabiin awal, baik dalam satu lembaran atau beberapa lembaran, hasilnya disebut sahifah. Fakta sejarah ada beberapa bukti ditemukannya sahifah-șahifah yang memuat catatan-catatan hadis dimaksud. ${ }^{69}$

Kata tadwin berasal dari kata Arab dawwana, secara bahasa berarti menghimpun, atau mengumpulkan. Kata masdarnya berarti "himpunan, kumpulan"70. Hal ini senada dengan apa

${ }^{66}$ M.M. Azami, Studies in Hadith Methodology..., hal. 27; M.M. Azami, Studies In Early Hadith..., h. 19.

${ }^{67}$ Harald Motzki menganalisa pandangan Alois Sprenger sebagai berikut; Nevertheless, already during the Prophet's lifetime, and then after his death, a few persons wrote hadiths down and Preserved them in this form, although there was a marked opposition against this practice. Harald Motzki, (ed.) 'Introduction Hadith: Origins and Developments" dalam The Formation of The Classical Islamic World, Vol. 28, (USA: The Cromwel Press, 2004), h. xv.

${ }^{68} \mathrm{Abi}$ al-Husain Ahmad bin Faris bin Zakaria bin Habib ar-Razi, Maqayis al-Lughah, jilid ke-5, h. 158, al-Maktabah asy-Syamilah, Edisi ke-2. Bandingkan dengan Muhammad bin Mukarram bin Manzhur, Lisan al-'Arab, jld. Ke-1, (Beirut: D=r al-Fikr, t.t.), h. 698.

${ }^{69}$ Manna' al-Qatțan, Mabāhis 'Ulūm al-Hadis, (Kairo: Maktabah Wahbah, 1992), h. 33.

${ }^{70}$ Muhammad Murtaḍa al-Husaini al-Wasithi al-Hanafi, Syarḥ al-Musammā 
yang diungkapkan az-Zahrani dalam memberi penjelasan kata tadwīn yakni mengikat (taqyīd) sesuatu yang terpisah, cerai berai dan mengumpulkannya ke dalam sebuah diwan atau buku yang memuat lembaran-lembaran. ${ }^{71}$ Definisi tersebut menjadi dasar bagi Azami bahwa tadwīn tidak mengandung arti penulisan (kitābah). Memang proses pengumpulan atau penghimpunan tersebut tidak mungkin meninggalkan kegiatan tulis menulis, tetapi kata tadwin tidak dimaksudkan untuk makna "menulis/mencatat" (do not mean writing down). ${ }^{72}$ Hal senada dijelaskan Manna al-Qatțan bahwa tadwinn adalah mengumpulkan lembaran-lembaran yang telah tertulis dan hafalan, disusun secara sistematis menjadi satu buku. ${ }^{73} \mathrm{Al}$-Baghdadi menjelaskan makna tadwīn dengan menyusun, mendaftar dan mengumpulkannya ke dalam suatu susunan atau buku (kitāb) yang terdiri dari beberapa lembaran. Tadwin ini lebih luas dari kata taqyid..${ }^{74}$ Secara terminologis, istilah tadwin hadis berarti usaha pengumpulan hadis yang tertulis dalam bentuk lembaran-lembaran atau yang masih ada dalam hafalan, lalu menyusun menjadi sebuah buku. ${ }^{75}$

Sedangkan kata taṣniff berasal dari kata șanafa-yașnifu- taṣ nifan berarti menyusun atau mengarang. Al-Baghdadi menjelaskan kata tașnif lebih dalam maknanya dibandingkan dengan tadwīn, yakni menyusun atau menghimpun sesuatu atas beberapa bagian dan bab tertentu menurut klasifikasinya ${ }^{76}$ tașnif hadì s; penyusunan hadis menurut tema dan kandungan ke dalam suatu kitab, di dua dekade awal abad kedua Hijriyah dan terus berkembang dengan berbagai tehnik, seperti berdasarkan urutan nama-nama periwayat mulai dari sahabat hingga tabiin (kitab musnad). Perkembangan selanjutnya hadis disusun berdasarkan kualitas nilai kesahihannya. ${ }^{77}$

Tāj al-'Arūs min Jawāhir al-Qāmūs, (Beirut: Dār al-Fikr, tt.), juz ke-9, h. 304.

${ }^{71}$ az-Zahrani, Tadwìn as-Sunnah.., h. 74.

${ }^{72}$ M.M. Azami, Studies In Early Hadith..., h. 20.

${ }^{73}$ al-Qatțan, Mabāhis..., h. 33.

${ }^{74} \mathrm{Al}-$ Baghdadi, Taqyìd al-Ilmi, ditahqiq oleh Yusuf al-'Isy, (Damaskus: t.tp., 1949), h. 8.

${ }^{75}$ al-Qațtan, Mabahis..., h. 33.

${ }^{76}$ Al-Baghdadi, Taqyīd...h. 8.

${ }^{77}$ Kamaruddin Amin, Menguji Kembali Keakuratan Metode Kritik Hadis, (Jakarta: Hikmah, 2009), cet. Ke-1, h. 121. Pendapat ini Amin kutip dari pendapat Fuat Sezgin yang lebih cenderung meyakini bahwa hadis dapat dipercaya secara 
Az-Zahranī menyamakan makna tadwīn dengan taṣnif. ${ }^{78}$ Meskipun dalam kesimpulan selanjutnya ia menjelaskan lebih jauh bahwa tas nif lebih mendalam artinya selain menghimpun, juga menyusun secara sistematis ke dalam beberapa bagian dan bab-bab tertentu. ${ }^{79}$

Beberapa definisi di atas oleh para penulis hadis dan pengarang atau penyusun kitab-kitab hadis tidak diperdebatkan maknanya, yang jelas mereka menulis, mengumpulkan, dan menyusunnya menjadi berwujud buku atau kitab. ${ }^{80}$ Sebab itu untuk menolong kualitas hafalan tentu tetap memerlukan tali pengikatnya, yakni tulisan. Dengan demikian maka ungkapan tentang orang Arab dahulu mengutamakan hafalan dalam menjaga tradisi dan budayanya tanpa diiringi tulisan maka itu amat sulit terjadi. ${ }^{81}$ Tulisan yang tersimpan itulah yang menjaga kekuratan apa yang tersimpan dalam dada. Rangkaian masa penulisan hadis di atas didasarkan pada kepercayaan bahwa hadis diriwayatkan tidak hanya melalui lisan semata, tetapi juga tertulis oleh para periwayat terpercaya dengan alat yang ada. Berdasarkan pada rangkaian urutan fase di atas dapat dipahami, az-Zuhri bukanlah orang yang pertama menulis hadis tetapi telah banyak dilakukan oleh umat Islam sebelumnya. ${ }^{82}$

Terkait dengan bahasan di atas, Azami melihat daya hafal tidak membutuhkan tulisan adalah tidak benar. Seseorang yang akan menghafal sesuatu berawal dari apa yang ia dapati dari tulisan, meski bukan tulisan tangannya sendiri. Dalam kasus ini bisa dilihat pernyataan al-Khatib al-Bagdadi di yang mengakui bahwa kaum salaf dalam menghafal membutuhkan tulisan, mereka menulis apa yang akan dihafal meski setelah menghafal tulisan tersebut ada yang dihapus agar tidak tergantung pada tulisan..$^{83}$

historis melalui fase-fase tersebut.

${ }^{78} \mathrm{Az}$-Zahrani, Tadwīn..., h. 11.

${ }^{79}$ Ibid., h. 74.

${ }^{80}$ M.M. Azami, Studies In Early Hadith... h. 1.

${ }^{81}$ M.M. Azami, Dirasah fi al-Hadis an-Nabawi wa Tarikh Tadwīnih, (Beirut: alMaktab al-Islami, 1985), h. 72.

${ }^{82}$ Muhammad bin Mathar az-Zahrani, Tadwīn as-Sunnah an-Nabawiyyah, Nasy'atuh wa Tat\} awaruh min al-Qarni al-Awwal ilā Nihāyah al-Qarni at-Tasi' al-Hijri, (Thaif: Maktabah al-Ṣadiq, 1412H), h. 83-85.

${ }^{83}$ al-Baghdadi, Taqyīd... h. 58. 
Azami memberi sanggahan kepada pandangan ulama termasuk Ibnu Hajar yang menyebutkan az-Zuhri adalah orang yang pertama menulis hadis ${ }^{84}$ Ibnu Hajar sebagaimana ulama lain berpandangan bahwa kalangan sahabat dan tabiin (salaf al- $\mathbf{s}$ $\bar{a}$ lih) lebih cenderung menyandarkan pada kekuatan hafalan dalam menjaga hadis daripada bersandar pada tulisan. Pandangan ini telah bergulir kepada banyak Sarjana muslim dan menjadi keyakinan kokoh. Muhammad bin Ja'far al-Kattāi juga sependapat bahwa kalangan sahabat dan tabiin hanya sedikit saja yang menulis hadis.$^{85}$

Kecenderungan ini terus berlanjut sampai pada akhir abad pertama Hijriyah, kala itu Umar bin Abdul Aziz selaku pemerintah mengkhawatirkan lenyapnya hadis di kalangan umat Islam dengan meninggalnya para penghafal hadis lalu memerintahkan Abi Bakar Muhammad bin Hazm untuk menulis sunnah atau hadis ${ }^{86}$ Perintah tersebut sebenarnya bukan hanya ditujukan kepada Abi Bakar Muhamad bin Hazm, tetapi kepada seluruh ulama dan mereka yang kapabilitas keilmuan hadis . Akan tetapi sebelum Ibnu Hazm secara lengkap melaksanakan intruksi tersebut, Umar bin Abdul Aziz telah wafat terlebih dahulu. Az-Zuhri adalah orang yang berhasil melakukannya di awal abad kedua Hijriyah Inilah yang membuat ia disebut sebagai orang yang pertama mengumpulkan atau mengkodifikasi hadis ke alam satu kitab atau mushaf/catatan khusus. Az-Zuhri sendiri pernah menyatakan bahwa dirinyalah orang yang pertama kali melakukan pengumpulan hadis (ilmu) kala itu dan tidak ada orang yang berhasil melakukannya. Sulaiman bin Daud pernah berkomentar tentang hal ini dan mengakui bahwa az-Zuhri memang orang yang pertama kali menyusun hadis (ilmu). Tetapi bukan berarti ia yang pertama kali menulis hadis , ia hanya mengkodifikasi dan menyusunnya. ${ }^{87}$

${ }^{84}$ al-Asqalani, Fath al-Bari..., h. 208.

85 as-Sakhāwi, Muhammad bin Abdur Rahman, Fath al-Mughis bi Syarh Alfiyah al-Ḥadīs li al- Irāqi, juz ke-3, (al-Qāhirah: Maktabah as-Sunnah, tt), h. 30-32; Muhammad bin Ja'far al-Kattāni, ar-Risālah al-Mustațrafah, cet. Ke-2 (Beirut: Dār alKutub al-Ilmiyyah, 1400 H), h. 3.

${ }^{86}$ Muhammad bin Ja'far Al-Kattāni, ar-Risālah ..., h. 4.

${ }^{87}$ Ibid. 
Sebenarnya al-Kattāni tidak sepenuhnya menyatakan kalangan salaf ash-shalih sama sekali tidak melakukan upaya menulis hadis . Ketegasaan ini terlihat dengan pengecualian yang ia tetapkan, ternyata ada juga sebagian sahabat yang menulis hadis sebagai koleksi pribadi dan rujukan hukum. Beberapa kitab as-șădiqah memuat kumpulan tulisan hadis yang dilakukan oleh beberapa sahabat yang bisa tulis menulis. ${ }^{88}$ Ada sebagian kitabkitab tersebut sampai kepada kita, dan ada yang hilang ditelan masa. Penulisan tersebut adakalanya atas izin Nabi dan ada yang melakukan penulisan atas inisiatif individu untuk kepentingan diri mereka sendiri. Contoh șahifah milik Sa'd bin 'Ubadah al-Anșarì, di mana beberapa hadisnya diriwayatkan oleh at-Tirmidzi dan al-Bukhari, șahifah milik Samrah bin Jundab (w. 60 H), șahifah milik Jabir bin Abdullah (w. 78 H), dan șaḥifah Abdullah bin 'Amr al-ṣ. ādiqah ${ }^{89}$

Abdullah bin 'Amr bin 'Ash menerangkan, sebagaimana dikutip al-Jaburi bahwa ia memiliki keinginan untuk menuliskan semua yang ia dengar dari diri Nabi saw dengan harapan di kemudian hari dapat menghafalnya. Akan tetapi hal itu dilarang oleh orang banyak (Quraisy) dengan alasan Nabi saw juga seorang manusia yang memiliki tabiat manusia, yang terkadang marah dan senang. Peristiwa itu dilaporkannya kepada Nabi saw. Ketika itu Nabi saw langsung memberi tanggapan yang membolehkan untuk melakukan penulisan karena semua yang diucapkannya adalah kebenaran. $^{90}$

Banyak kalangan memahami ungkapan para ulama tentang penyebaran hadis melalui lisan karena bisa saja kurang tepat di dalam memahami dan komprehensif melihat peryataan ulama tersebut. Misalnya penyataan al-Kattāni yang hanya berhenti pada kalimat:

$$
\text { لا يكتبون الحديث ولكنهم يؤدونه لفظا ويأخذونه حفظا. }
$$

Padahal al-Kattāni belum selesai dalam menggambarkan

${ }^{88} \mathrm{Abu}$ al-Yaqzan 'Ațiyah al-Jabūri, Mabāḥis fi Tadwīn as-Sunnah al-Muțahharah, (Beirut: Dār an-Nadwah al-Jadidah, tt.), h. 135.

${ }^{89}$ Ibid., h. 136.

${ }^{90}$ Ibid. 
keadaan sahabat dan tabi'in di atas terkait mereka lebih mengutamakan periwayatan dengan lisan dan hafalan. Pernyataannya akan lebih lengkap jika melihat kalimat sesudahnya yakni: إلا كتاب الصدقة وشيئا يسيرا.

Dampak dari pemahaman yang tidak lengkap tersebut oleh orang-orang yang memiliki kecenderungan dan niat tidak baik akan ajaran Islam dapat saja menyatakan bahwa memang sahabat dan tabiin tidak melakukan tulis menulis tentang hadis Nabi saw. ${ }^{91}$ Mereka dengan sepihak mengungkapkan dalil dari hadis Nabi yang melarang untuk menulis hadis yang bersifat kasuistis lalu digeneralisasikan untuk semua sahabat dan tabiin seraya menyembunyikan hadis -hadis yang membolehkan menulis hadis dan tidak melihat fakta sejarah yang menjelaskan adanya bukti tulisan berupa hadis yang ada pada sebagian sahabat.

Azami melihat jika benar umat Islam di masa Nabi masih hidup tidak semuanya pandai menulis, tentu tidak mungkin Nabi memberikan larangan menulis selain al-Qur'an. Logikanya, jika hal tersebut benar lalu bagaimana al-Qur'an dapat tertulis dan kenyataannya Nabi memiliki juru tulis (sekretaris) untuk menuliskan al-Qur'an. ${ }^{92}$ Hal yang sama juga diungkapkan al-Baghdi di saat memberi analisa atas pernyataan az-Zuhri sebagai orang yang pertama menulis hadis . Menurutnya mereka yang sepaham dengan pandangan di atas berarti tidak menyandingkan dengan adanya larangan Nabi menulis hadis dan tidak pula memahami kandungannya secara benar. ${ }^{93}$ Al-Bagdadi mengutip pandangan Abu Țālib al-Makki yang menyatakan keengganan kalangan tabi'in besar menulis hadis, tetapi mengutamakan hafalan sampai masa Hasan (w. 110 H) dan Ibnu al-Musayyab (w. 115 H). ${ }^{94}$ Ungkapan senada dinyatakan oleh al-Żahabi bahwa sahabat dan tabi'in mengandalkan kekuatan hafalan dalam dada yang merupakan gudang ilmu mereka. ${ }^{95}$

${ }^{91}$ Al-Baghdadi, Taqyīd..., h. 7.

${ }^{92}$ M.M. Azami, Dirasah... , h. 71.

${ }^{93}$ Al-Baghdadi, Taqyīd..., h. 6.

${ }^{94}$ Ibid..., h. 6.

${ }^{95}$ Syamsuddin Muhammad bin Ahmad al-Żahabi , Tażkirah al-Ḥuffādz, jilid ke-1 (Beirut: Dār al-Kutub al-Ilmiyyah, 1963), h. 151. 
Beberapa ulama menyetujui pandangan tentang kemahiran dan kekuatan hafalan orang Arab di masa sebelum datangnya Islam. Keadaan ini terus berlangsung turun temurun sampai masa sahabat dan tabiin. Uraian al-Żahabi dan al-Makki di atas bila disingkronkan dengan tuntunan al-Qur'an yang menganjurkan untuk belajar dan menuntut ilmu jauh berbeda. Bukankah sejak pertama wahyu diturunkan telah mengisyaratkan pentingnya membaca. Allah juga jelas-jelas memberikan dorongan agar umat Islam tidak pergi berperang secara keseluruhan tetapi ada beberapa orang yang hendaknya memperdalam ilmu agama. ${ }^{96}$ Azami melihat pandangan yang mengemukakan ketiadaan orang Islam yang mampu menulis dan membaca di masa awal sejarah Islam tidak sepenuhnya benar. Betapa banyak anjuran dan perintah Nabi saw agar umat Islam belajar menulis dan membaca. Azami mengilustrasikan bahwa Nabi menyuruh beberapa orang sahabat untuk mengajarkan tulis menulis, di antaranya ialah 'Ubadah bin Shamit dan lainnya. ${ }^{97}$ Kepedulian Nabi dan kesadaran sahabat yang mau mengajarkan tulis menulis memberi kejelasan, di masa awal Islam saja ada yang pandai menulis dan mengajarkannya kepada orang lain.

Brown justeru meragukan keberadaan hadis telah tercatat di masa Nabi saw. Menurutnya, penulisan secara sistematis terhadap hadis baru dilakukan pada saat maraknya konflik perpecahan teologis dan politis dalam dunia Muslim. Konflik ini bahkan bermula jauh sebelumnya, sejak penghujung kepemimpinan Ali bin Abi T ālib sebagai Khalifah keempat pasca terbunuhnya Usman bin Affan. Dalam situasi fitnah masa-masa selanjutnya, tidak hanya penulisan sistematis terhadap hadis dilakukan, tapi mulai juga dibangun sebuah metodologi (sanad). Metode ini dianggap dapat diandalkan untuk mendapat kepastian bahwa sebuah hadis benar-benar pernah disampaikan, atau contoh perbuatannya pernah dilakukan sendiri oleh Nabi Muhammad Saw. ${ }^{98}$ Uraian Brown ini seiring dengan para pendahulunya, Goldziher dan Schacht. Selain menggarisbawahi keraguan penulisan hadis di masa Nabi, penulisan hadis baru dilaksanakan sebagai reaksi dari adanya konflik horisontal yang

\footnotetext{
${ }^{96}$ Al-Qur'an Surat at-Taubah: 122.

${ }^{97}$ M.M. Azami, Dirasah..., h. 50.

${ }^{98}$ Daniel W. Brown, Rethinking Tradition.... h. 93-100.
} 
ada di kalangan umat Islam. Sistem isnad juga dianggap baru ada pada masa setelah fitnah berlangsung.

\section{E. Penutup}

Goldziher adalah seorang pakar yang telah jauh menelaah tradisi keilmuan Islam, khususnya al-Qur'an dan hadis Nabi. Pemikiran utama goldziher terhadap hadis tidak bisa dipandang sebelah mata, sebab implikasinya cukup luas terhadap para orientalis yang concern terhadap studi hadis. Inti pemikiran Goldziher adalah meragukan keberadaan hadis, sebab asal muasal hadis bukan benar-benar berasal dari Nabi Muhammad saw. Melainkan dari kebiasaan dan tradisi masyaraakat Islam masa awal. Tradisi ini agar dapat diterima kemudian disandarkan kepada Nabi saw. hadis juga merupakan sesuatu yang adop dari masyarakat luar Islam, kemudian menjadi tradisi masyarakat muslim. Selain itu hadis pantas diragukan, sebab masa awal Islam telah nyata banyaknya pemalsuan hadis dari kalangan muslim sendiri.

Azami tampil sebagai pemikir yang kontra atas pemikiran orientalis, khususnya Goldziher. Menurut Azami hadis adalah peninggalan berharga yang berasal dari Nabi Muhammad saw. Keterjagaan dalam periwayatan dan penulisan hadis dapat diterima dan dipercaya. Berbagai bukti nyata dapat dilihat, baik dari berbagai riwayat, tulisan sahabat, tabi'in, dan literatur lain yang mendukungnya. Periwayatan hadis dalam Islam merupakan kelebihan umat Islam, dan tiada umat lain yang memilikinya. Pemikiran Goldziher tidak mendasar dan hanya bertumpu pada keraguan semata. Latar belakang akan kebencian goldziher terhadap Islam cukup dijadikan sebagai tolok ukur dalam menilai pemikirannya.

\section{Daftar Pustaka}

Akaha, Abduh Zulkidar, Al-Qur'an dan Qira'at, Jakarta: Pustaka alKautsar, 1996.

Amin, Kamaruddin, Menguji Kembali Keakuratan Metode Kritik Hadis, Jakarta: Hikmah, 2009, cet. Ke-1. 
Azami, M.M., 65 Sekretaris Nabi Shallallahu 'Alaihi wa Sallam, terj. Mahfuzh Hidayat Lukman, cet. ke-1, Jakarta: Gema Insani Press, 2008.

, Dirasah fi al-Hadīs an-Nabawi wa Tarikh Tadwīnih, Beirut: alMaktab al-Islami, 1985.

, Studies In Early Hadith Literature With A Critical Edition of Some Early Tekts, Beirut: Al-Maktab al-Islami, 1968.

, Studies in Hadith Methodology and Literature, Indianapolis: American Trust Publications, 1977.

al-Asqalāni, Syihab ad-Dîn Abi al-Fadl bin Hajar (773-852 H), Fath alBāri bi Syarh al-Bukhāri, jld. I, Kairo: Maktabah Mustafa al-Bābi al-Halabi, $1951 \mathrm{M} / 1378 \mathrm{H}$.

al-Baghdadi, Taqyīd al-Ilmi, ditahqiq oleh Yusuf al-'Isy, Damaskus: t.tp., 1949.

al-Dārimi, Abu Muhammad Abdullah bin Bahram, Sunan al-Dārimi, jld. I, (Beirut: Dār al-Fikr, 2005.

Gibb, H.A.R \& Kramers, J.H., Shorter Encyclopaedia of Islam, London: Luzac \& Co, and Leiden: E.J. Brill, 1961.

Goldziher, Ignaz, Introduction to Islamic Theology dan Law, terj. Andras dan Ruth Hamori, Princeton: Princeton University Press, 1981.

, Muslim Studies, terj. S.M. Stern \& C.R. Barber, London: George Allen \& Unwin, 1971.

al-Hanafi, Muhammad Murtaḍa al-Husaini al-Wasiți, Syarh alMusammā Tāj al-'Arūs min Jawāhir al-Q̄àmūs, Beirut: Dār al-Fikr, tt., juz ke-9.

Hasan, Ahmed, The Early Development of Islamic Jurisprudence, edisi ke-1, Delhi, India: Adam Publishers \& Distributors, 1994.

Hasyim, Ahmad Umar, as-Sunnah an-Nabawiyah wa 'Ulümuha, Fajalah: Maktabah Gharib, t.t.

Khatib, Muhammad Ajjaj, Uṣ̂̄l al-Hadis 'Ulūmuhu wa Must\}alahuh, cet. ke-3, Beirut: Dār al-Fikr, 1975.

Al-Kattāni, Muhammad bin Ja'far, al-Risālah al-Mustațrafah, cet. Ke-2, Beirut: Dār al-Kutub al-'Ilmiyah, $1400 \mathrm{H}$.

Manzur, Muhammad bin Mukarram bin, Lisān al-Aarab, jld. Ke-1, Beirut: Dār al-Fikr, tt.. 
Motzki, Harald, (ed.) 'Introduction Hadith: Origins and Developments" dalam The Formation of The Classical Islamic World, Vol. 28, USA: The Cromwel Press, 2004.

al-Qațțan, Manna', Mabāhis 'Ulūm al-Hadīs, Kairo: Maktabah Wahbah, 1992.

ar-Razi, Ahmad, Husain bin Faris bin Zakaria bin Habib, Maqayis alLughah, jilid ke-5, al-Maktabah asy-Syamilah, Edisi ke-2.

Schoeler, Gregor, The Oral and The Written in Early Islam, Trans. Uwe Vagepohl, diedit oleh James E. Montgomery, cet. Ke-1, (London and New York: Routledge Taylor and Franch Group.

as-Sakhawi, Muhammad bin Abdur Rahman, Fath al-Mughits bi Syarh Alfiyah al-Hadīs lil Iraqi, juz ke-3, al-Qahirah: Maktabah asSunnah, tt.

az-Zahrani, Muhammad bin Mațar, Tadwīn as-Sunnah an-Nabawiyyah, Nasy'atuh wa Tațawaruh min al-Qarni al-Awwal ilā Nihāyah alQarni at-Tasi' al-Hijri, Thaif: Maktabah al-Ṣadiq, 1412H.

az-Zahabi, Syams al-Dỉn Muhammad bin Ahmad, Tażkirah al-Huffādz, jilid ke-1 , Beirut: Dār al-Kutub al-Ilmiyyah, 1963

az-Zarqāni, Muhammad Abdul À̇īm, Manāhil al-Irfān fi 'Ulūm alQur'ān, juz ke-1, Mesir: Maktabah Isa Al-Bābi al Halabi, tt.. 